\title{
Progettare il cambiamento del welfare locale. Il caso WeIMi a Milano
}

Massimo Bricocoli, Stefania Sabatinelli

Politecnico di Milano, Dipartimento di Architettura e Studi Urbani (massimo.bricocoli@polimi.it; stefania.sabatinelli@polimi.it)

La sperimentazione di nuove forme e luoghi di accesso al welfare è un terreno poco esplorato di ricerca e di pratiche all'incrocio tra progetto delle politiche e organizzazione dei servizi sociali, progetto urbano e regolazione urbanistica, progetto architettonico, progetto e design della comunicazione. Il servizio rende conto dell'attività di consulenza scientifica e di ricerca condotta nell'ambito del progetto Welfare di tutti che costituisce un caposaldo nella riforma del sistema di welfare della città di Milano.

Presupposti, temi e questioni centrali, metodo ed esiti di una prima fase del progetto sono qui restituiti in forma di riflessione e mettendo in evidenza il contributo del Politecnico di Milano con riferimento a diversi apporti disciplinari

Parole chiave: welfare locale; spazi del welfare; Milano
Ricerche e riflessioni sulle connessioni tra politiche di welfare e politiche urbanistiche e, in particolare, sulla configurazione che i servizi sociali assumono in termini di spazi concreti appaiono ancora assai limitate. Le qualità spaziali delle risorse di welfare, le loro caratteristiche materiali ed estetiche, sono dimensioni generalmente trascurate nella progettazione dei servizi. Eppure, le qualità spaziali rivestono grande importanza per le modalità e gli esiti degli interventi sviluppati dai e nei servizi di welfare. Il servizio monografico che presentiamo in queste pagine propone una serie di riflessioni a partire da un'attività di ricerca e di partecipazione attiva alla concezione e allo sviluppo del progetto Welfare di tutti che costituisce un caposaldo nella riforma del sistema di welfare e dei servizi sociali a Milano. Il progetto, cofinanziato da Fondazione Cariplo, è promosso dal Comune di Milano insieme a 16 partner tra i quali due dipartimenti del Politecnico di Milano con funzioni di supporto scientifico e

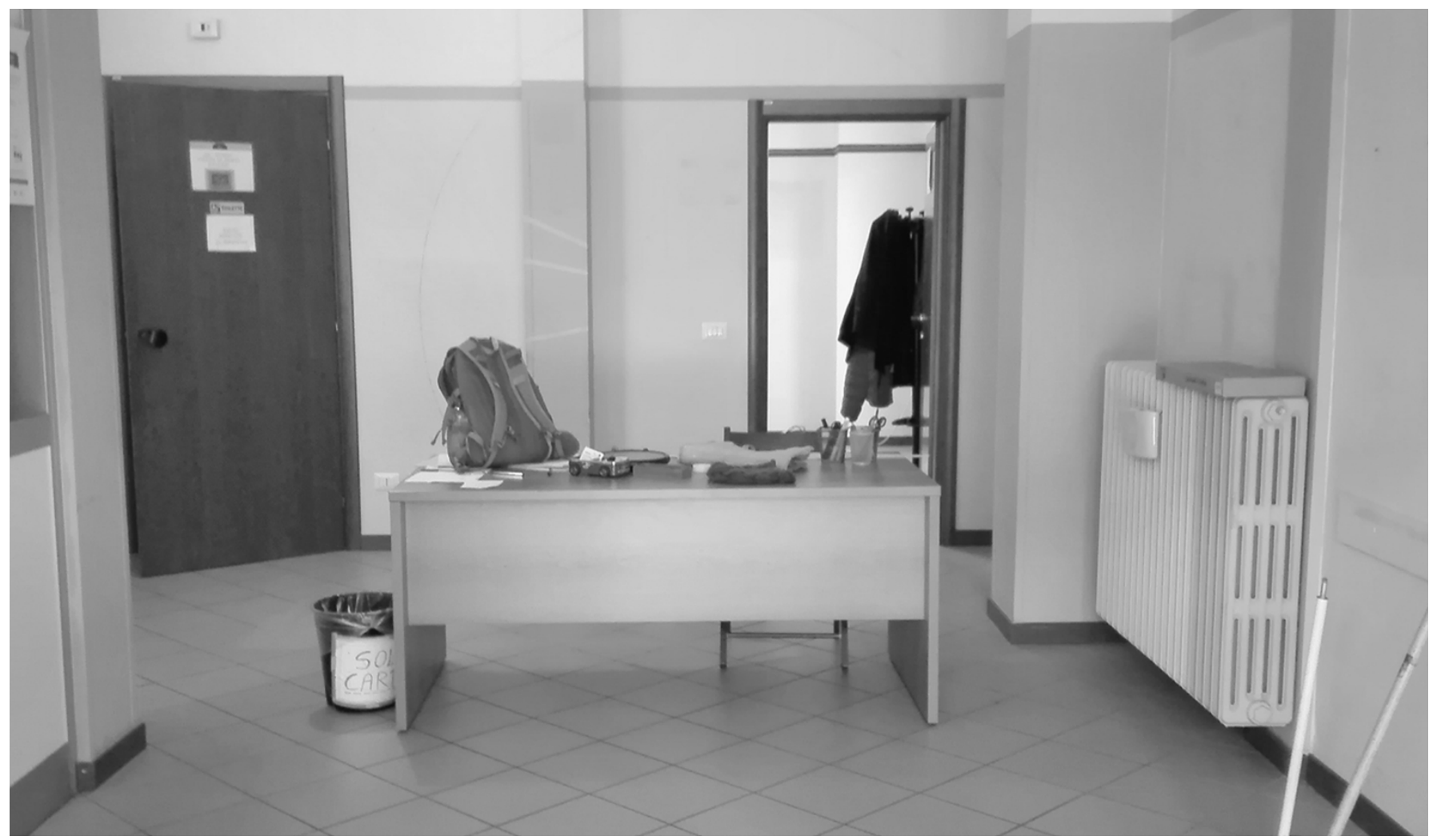




\section{Designing Change and Innovating Local Welfare. The Case of the WeMi Project in Milan}

The experimentation of new forms and places of access to welfare defines an interesting research and practice field at the edge of policies and organization of social services, urban planning, architectural design, communication project and design. In the following articles we reflect on the scientific consulting and research activities carried out within the project Welfare di tutti, which represents a cornerstone in the reform of the local welfare system of the city of Milan. Premises, themes and issues, methods and outcomes of a first phase of the project are summarized here, highlighting the contribution of the Politecnico di Milano with reference to different disciplinary approaches

Keywords: local welfare; welfare spaces; Milan metodologico: il Dipartimento di Architettura e Studi Urbani (gruppo di lavoro: Massimo Bricocoli e Stefania Sabatinelli, coordinatori; Benedetta Marani, Francesco Curci e Lorenzo Consalez) e il Dipartimento di Design (gruppo di lavoro: Valeria Bucchetti, coordinatrice; Umberto Tolino e Pamela Visconti con Paolo Panzuti Bisanti). Un'azione centrale del progetto consiste nella creazione di una piattaforma digitale per l'incontro di domanda e offerta di servizi di welfare forniti da enti accreditati. Un secondo ambito di azione consiste nella sperimentazione di cosiddette 'piattaforme territoriali', denominate spazi $W e M i$, ovvero luoghi fisici, deputati all'incontro concreto con i cittadini, al loro orientamento verso le risorse e i servizi presenti in città. Obiettivo principale della sperimentazione è quello di innovare immagine e modalità di accesso al welfare cittadino. Temi e questioni centrali emersi in una prima fase del progetto sono restituiti mettendo in evidenza il contributo dei ricercatori del Politecnico di Milano coinvolti con riferimento a diversi apporti disciplinari. In una prospettiva politecnica, la sperimentazione di nuove forme e luoghi di accesso al welfare definisce un terreno interessante di ricerca e di pratiche all'incrocio tra politiche e organizzazione dei servizi sociali, regolazione urbanistica, progetto urbanistico e architettonico, design della comunicazione.

Due specifici casi sono illustrati quali sperimentazioni di frontiera rispetto all'innovazione delle politiche e dei progetti di welfare: uno spazio innovativo di accesso ai servizi di welfare e il disegno dell'identità visiva del progetto.

Le immagini documentano la realizzazione della parete di WeMi Capuana (prima e dopo)

Fonte archivio dell'autore 2016

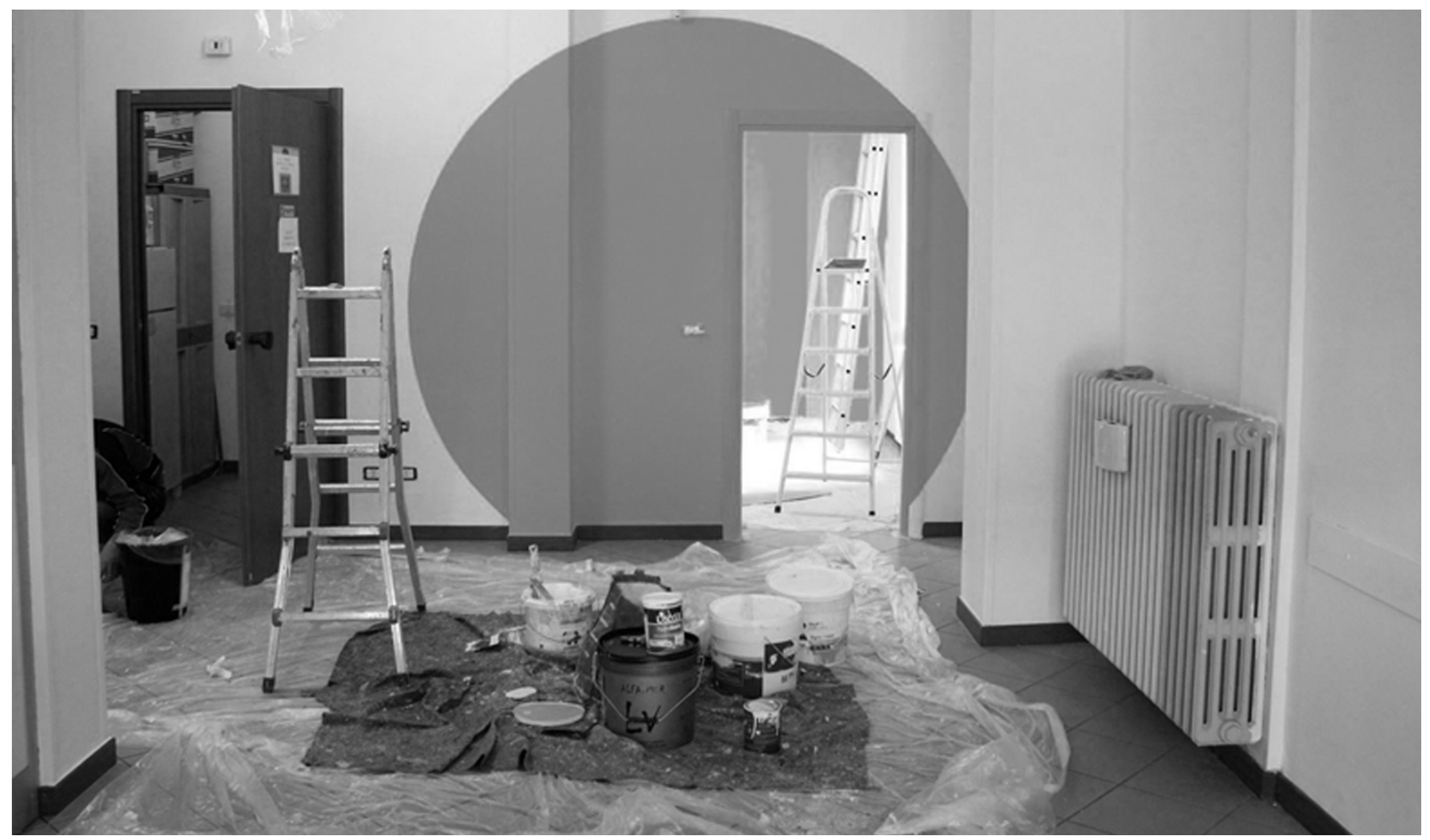

69 | Territorio 